\title{
Conceptual Difficulties of Secondary School Students in Electrochemistry
}

\author{
Muzammila Akram ${ }^{1}$, Johari Bin Surif ${ }^{2} \&{\text { Murad } \mathrm{Ali}^{3}}^{3}$ \\ ${ }^{1}$ Department of Science \& Mathematics Education, Universiti Teknologi Malaysia; Department of Educational \\ Training, Islamia University Bahawalpur, 63100, Pakistan \\ 2 Department of Science \& Mathematics Education, Universiti Teknologi Malaysia \\ ${ }^{3}$ Department of Chemistry, Government S.E. College, Bahawalpur, Pakistan \\ Correspondence: Muzammila Akram, Department of Science \&Mathematics Education, Universiti Teknologi \\ Malaysia, 81310, (UTM); Department of Educational Training, Islamia University Bahawalpur, 63100, Pakistan. \\ E-mail: muzammilamurad@yahoo.com
}

\author{
Received: September 10, 2013 Accepted: September 23, 2014 Online Published: September 29, 2014 \\ doi:10.5539/ass.v10n19p276 URL: http://dx.doi.org/10.5539/ass.v10n19p276
}

\begin{abstract}
This study designed primarily to explore conceptual difficulties of secondary school students to understand the basic features of the concept of electrochemistry like redox reactions, galvanic and electrolytic cells. Furthermore, the factors that cause the conceptual difficulties of secondary school students in electrochemistry also investigated. Mixed method research design adopted to achieve the objectives of the current study. Three (3) government secondary schools selected by using the cluster random sampling technique within Bahawalpur City of Pakistan. Then 144 chemistry students of IX class purposively selected as sample of the study. Conceptual difficulties of secondary school students in electrochemistry investigated by developing a special test instrument tagged as Test designed to measure the Conceptual Difficulties in Electrochemistry (TCDE). Eminent experts of chemistry education validated TCDE. A pilot test established to find its reliability by test re-tests method and the correlation coefficient ( $r$ ) was 0.96 . The Cronbach alpha coefficient also calculated to measure the internal consistency of instrument through SPSS, and its value was 0.87 . Thirty students selected purposively based on the result of TCDE for semi-structured interview. The result showed that $67 \%$ of the concept-based items designed in electrochemistry were difficult to understand by secondary school students. Poor background of knowledge, absence of teaching aids, and misunderstanding of language caused conceptual difficulty in comprehension. The findings suggested some recommendations to expedite better understanding of the chemistry students.
\end{abstract}

Keywords: conceptual difficulties, electrochemistry, factors of conceptual difficulties, secondary school students

\section{Introduction}

Chemistry education (or chemical education) is a comprehensive term that refers to the process of teaching and learning in chemistry subject at all educational institutions. Chemistry education is facing many challenges in most of the countries at secondary level. These challenges cannot be overcome only by considering the teaching of chemistry. Nevertheless, it requires a comprehensive effort to assess conceptual knowledge of chemistry that school students learn in secondary schools (Lamanauskas, 2007).

Several studies in the chemistry education literature dealt with the learning difficulties of basic concepts of chemistry at schools. Concepts formed when the ideas or thoughts are developed based on common properties of objects or events by the process of abstraction (American Heritage Dictionary, 2002). Difficulty or problems in pertaining to concepts or to the forming of concepts referred as conceptual difficulties. Duit (2007) described that students hesitate to answer the questions set on those concepts that are difficult for them. Student's conceptual difficulties in chemistry created a major problem of concern to science educators, teachers, and students (Ozmen, 2004). Electrochemistry regarded as one of the most difficult chemistry concepts in which both pre-service teachers and students have learning difficulties (Nakhleh, 1992; Ogude, 1994; Ozkaya, 2002). For the current study, topic of electrochemistry selected for following reasons. 
1. Electrochemistry considered as a difficult topic for students to learn and for teachers to teach. A survey conducted to rate the most difficult chemistry topics at schools and the top three were chemical equilibrium, the mole, and oxidation-reduction reactions (Finley, Stewart, \& Yarroch, 1982).

2. Principles of electrochemistry have general applications used in routine e.g. electroplating established based on the principle of electrolytic cell. Students should acquaint such knowledge (Ahtee, Asunta, \& Palm, 2002).

3. The topic of electrolysis is common in physics and chemistry. Sometimes, it cause confusion and students did not freely assimilate their knowledge across physics and chemistry (Taber, 1998).

Garnett and Treagust (1992) investigated high school students' understanding of electrochemistry in terms of electrochemical and electrolytic cells. Sanger and Greenbowe (1997) replicated the study of Garnett and Treagust (1992) with college chemistry students and found similar findings with them as students had learning difficulties in galvanic, electrolytic and concentration cells. Moreover, they emphasized that identifying conceptual difficulties was important to help learners understand this topic meaningfully. Obomanu (2012) also identified the conceptual difficulties of Nigerian secondary school pupils in electrolysis through concept inventory. The conceptual difficulties of students may change with the change in variables like gender, age, culture, religion and geographical region (Losh, et al, 2003).

Literature supplied with evidence that Pakistani students find chemistry difficult and uninteresting. Chemistry is the compulsory subject for all secondary school students of science group in Pakistan. The pass percentage in the subject of chemistry is very low, about $50 \%$ (Table 1 ).

Table1. Students Result in SSC (Secondary School Certificate) Examinations in the subject of Chemistry for Class IX (2009-2013)

\begin{tabular}{cccc}
\hline Year & $\begin{array}{c}\text { Total no. of Students appeared in SSC (IX) } \\
\text { Examination }\end{array}$ & $\begin{array}{c}\text { No. of Passed } \\
\text { Students }\end{array}$ & $\begin{array}{c}\text { \% age of Passed } \\
\text { Students }\end{array}$ \\
\hline 2009 & 43367 & 20841 & 48.05 \\
2010 & 46433 & 22972 & 49.47 \\
2011 & 49870 & 21643 & 43.39 \\
2012 & 54294 & 29782 & 54.85 \\
2013 & 55300 & 31054 & 56.15 \\
\hline
\end{tabular}

(Source: Bahawalpur Board of Intermediate \& Secondary Education)

The factors contributed to this problem might be poor methods of instruction, laboratory inadequacy, poor science background, and passive role of students etc. Research in chemistry education showed that students feel difficulty to understand the abstract natured chemistry concepts and many researches conducted in advanced countries to identify their conceptual difficulties and find out possible solutions (Nakhleh, 1992; Ogude, 1994; Ozkaya, 2002; Garnett \& Treagust, 1992). However, in Pakistan and in many developing countries, very little research work has done in this domain; particularly no serious attempt has made to overcome the existing problem.

\subsection{Research Questions}

Therefore, present study designed to seek the answers to the following questions.

1. Which concepts in electrochemistry are most difficult to understand for chemistry students?

2. What are the factors that cause the conceptual difficulties of secondary school students in electrochemistry?

\section{Research Method}

The current study adopted mixed method research design. Both quantitative and qualitative research methods adopted harmoniously. The topic of electrochemistry is present in IX class of Punjab Text Book Board Syllabus of Chemistry. Hence, target population consisted of all students of IX class, learning chemistry in Bahawalpur City of Pakistan. Three (3) government secondary schools out of (11) were selected by using the cluster random sampling technique within Bahawalpur City of Pakistan. Then 144 chemistry students of IX class purposively selected as sample of the study. Conceptual difficulties of secondary school students in electrochemistry investigated by developing a special test instrument tagged as Test designed to measure the Conceptual Difficulties in Electrochemistry (TCDE). Based on result of TCDE the 30 students selected purposively for 
semi-structured interview. Moreover, Think Aloud Protocol sheet given to each student during interview. The conversations recorded and the responses analyzed to identify the most difficult concepts in sub topics of electrochemistry and factors that cause student's conceptual difficulties.

\subsection{Validity and Reliability of Instrument}

A distinguishing concept inventory for measuring student's conceptual difficulties in electrochemistry (TCDE) developed keeping in view the objectives of the study. The content validity of TCDE ensured after checking and consulting 10 eminent chemistry teachers. The test instrument consisted of 30 MCQ's constructed according to Punjab Text Book Board Syllabus of Chemistry for class IX. The selected topics were as follows: oxidation and reduction, oxidation states and rules for assigning the oxidation states, oxidizing and reducing agents, oxidation and reduction reactions and electrochemical cells. An attempt was made to minimize guessing by including four options in each item. TCDE was pilot tested to find its reliability by test re-tests method and the correlation coefficient (r) was 0.96.The Cronbach alpha coefficient also calculated to measure the internal consistency of instrument through SPSS and its value found to be 0.87 .

Think Aloud Protocol sheet designed by researchers to differentiate between electrolytic cell and galvanic cell in the light of related literature (Garnett \& Treagust, 1992; Sanger \& Greenbowe, 1997). Moreover, suggestions of five experts in chemistry education were taken into consideration while developing the questions of interview and sheet. The questions of interview were concentrated on students' previous knowledge \& their background, teaching techniques, use of visual aids and students active participation during lecture etc.

\subsection{Data Analysis}

The quantitative data obtained through TCDE entered in SPSS 17 (Statistical Package for Social Sciences) for analysis, and the percentage of each correct and incorrect item was calculated. A norm established to measure the item difficulty in TCDE. Below $40 \%$, students` correctly answered item considered as difficult (Obomanu, 2012). The qualitative data obtained through interview of students recorded. Qualitative content analysis (Creswell, 2009) used in order to analyze the recorded data of interview and written responses of the sheet. Two researchers analyzed the responses of students separately and independently. Later on, they came together and discussed the answers to reach consensus.

\section{Results \& Discussion}

The results of the analysis of TCDE showed that $67 \%$ of the concept-based items designed in electrochemistry were difficult to understand by secondary school students. The table II (given in appendix) showed that only $2.8 \%$ and $7.6 \%$ of the students answered correctly the Items $16 \& 27$ respectively, which means the most difficult concepts to understand, are conduction of electrolysis and mechanism of electrolysis and its practical application. The other difficult concepts are: product gotten at anode (11.1\% in item no.3), redox reaction $(13.9 \% \& 33.3 \%$ in items no. 5 \& 1 respectively), concept of oxidation (19.4\% in item no. 28$)$, oxidizing agent ( $20.8 \% \& 30.5 \%$ in item no. $9 \& 15$ respectively), reducing agent (20.8\% in item no. 22$)$, and oxidizing\& reducing agent ( $36.8 \%$ in item no. 30). Furthermore, the concepts of; charges on electrodes (item $4 \& 14$ ), concept of anode $\&$ cathode (item 20,23$)$, oxidation $(17,29)$, oxidation state (item 25), non-conductors (item 26), were also found to be difficult. However, students did not have difficulty in understanding the concepts of; change during electrolysis (item 2), calculations of oxidation number (items $6 \& 10$ ), definition of electrochemical cells and oxidation (items 11, $19 \& 24$ ), example of redox reaction (item 7), non electrolyte, electric circuit, electric conductor (items $8,12 \& 13$ ).

The results of the analysis of interview questions examining each area discussed below. The student's responses about the most difficult concepts in the electrochemistry analyzed and classified into the following areas:

- Conduction of electrolysis by ions

- Mechanism of electrolysis and its practical application

- Redox reaction

- Oxidizing agent \& reducing agent

- Product gotten at anode and cathode

The result obtained through interview technique, strengthened the results obtained through quantitative data of TCDE.

The student's responses about the factors of conceptual difficulties analyzed and results indicated that some of the participants gave irrelevant responses to the question. However, majority reported the factors such as; poor 
background of knowledge, absence of teaching aids, rote learning, saturated classes, misunderstanding of language and passive role of students, which caused difficulty in comprehension. Twelve students out of thirty reported that their mathematics teacher was teaching them chemistry. The results obtained through quantitative data of TCDE also proved that these students calculated the oxidation number very well but failed to explain the mechanism. Previous researches also pointed out that some teachers failed to provide accurate information to students and they presented the concepts poorly. Teachers can also be a source of misconceptions because most students regard their teachers as experts and consider their words as correct (Ogude, 1994; Ozkaya, 2002).

When the students were questioned whether they fully understand what was taught, majority of them (19 out of 30 respondents) reported that they did not understand because their teachers used only the board and diagrams of textbook with lecture method. The other (11) students mentioned that their teachers also used discussion technique and encouraged them to ask questions about the difficulties and tried to illustrate with supplementary materials and examples.

For the question, "does your teacher explore your previous knowledge about the topic" majority (21 out of 30 respondents) reported that usually their teachers asked about the previous lecture but not the previous knowledge of the topic. When the students were questioned if their teachers encouraged collaboration with their fellows after instruction, majority ( 27 out of 30 respondents) claimed that it happened sometimes not all the times. None of them could give any example of practical application of electrolysis.

Results of the written responses of think aloud protocol sheet indicated that 16 students out of 30 gave the apparent difference between the electrolytic cell and galvanic cell. They considered the salt bridge as a basic difference between the two cells. While the correct and basic difference between two cells is that in galvanic cells the reaction is spontaneous while in electrolytic cells the reaction is nonspontaneous. The term spontaneous was ambiguous to the students. Many students asked from the researcher, 'what is the meaning of spontaneous?' during the interview. Some students considered the meaning of spontaneous as 'all at once' instead of 'without input'. Majority (23 out of 30 groups) believed that electrons could flow through the solutions and the salt bridge to complete the circuit in galvanic cell. For example, Zahra explained as, "Electrons move through solution...because negative ion attract positive ion." Summayya explained as, "Electrons move through solution due to attraction of opposite pole". The misunderstanding of words seemed to develop conceptual difficulty as Zahra and Summayya were mixing up the words of 'electrons' with negative ion'. Only seven students answered correctly that anions and cations flow through the salt bridge and the solution. Moreover, majority (26 out of 30 groups) responded correctly and identified that anode is positive and cathode is negative in electrolytic cell and vice versa in galvanic cell.

\section{Recommendations}

Following recommendations drawn based on findings:

1. The most difficult concepts to understand are; conduction of electrolysis and mechanism of electrolysis. This may be due to its abstract nature. Sanger \& Greenbowe (1997) recommended teachers to use computer-animated instruction for teaching abstract natured topics like electrochemistry. However, lack of computers and inadequate laboratory apparatus is a big problem in Pakistan and in many other developing countries. Hence, it is recommended that teachers should use demonstration methods with low cost teaching aids during instruction. Teachers made cells may be prepared simply with the help of low cost materials like beaker, lemon water, carbon rods of old cells, wire, and bulb. This simple cell used to make circuit so that conduction of electrolysis and mechanism of electrolysis could be better understood.

2. The findings propose several suggestions for teaching the topic of electrochemistry to expedite conceptual understanding of students. Teachers should encourage students to participate actively during lesson and collaborate with their fellows after instruction. Rote learning should be discouraged.

3. Several research studies conducted to cope with identified conceptual difficulties. For example, using cooperative learning instruction (Acar \& Tarhan, 2007), conceptual change instruction (Ozkaya, 2002), or use of designed teaching sequence (Ahmad \& Lah, 2013). However, no research study proposed a proper instructional model that can be specifically prepared in the context of developing countries like Pakistan. Hence, it is recommended to develop a constructivist instructional model for further research that may help the teachers to probe the conceptual difficulties of their students.

4. Language misunderstanding found to be an important factor that causes conceptual difficulties. Vygotsky (1978) claimed that concepts could not be acquired in conscious form without language. Concepts should be 
explained in a related context using language. Further researches are recommended to explore the role of language in developing the conceptual difficulties.

5. Keeping in view the findings of the study it is also recommended that teachers should explore the previous knowledge of the students e.g., Valency and balancing the equation should be revised before giving the knowledge of oxidation state. Knowledge of electrolytes and its types provide base for conduction of electrolysis.

\section{References}

Acar, B., \& Tarhan, L. (2007). Effect of cooperative learning strategies on students' understanding of concepts in electrochemistry. International Journal of Science and Mathematics Education, 5, 349-373. http://dx.doi.org/10.1007/s10763-006-9046-7

Ahmad, N. J., \& Lah, C. Y. (2013). A designed teaching sequence as a tool to improve students 'conceptual understanding of the conductivity in the electrolytic cell. Asian Social Science, 9, 298-304. http://dx.doi.org/10.5539/ass.v9n2p298

Ahtee, M., Asunta, T., \& Palm, H. (2002). Student teachers' problem in teaching 'electrolysis' with a key demonstration. Chemistry Education: Research and Practice in Europe, 3(3), 317-327. http://dx.doi.org/10.1039/b0rp90031a

Concept formation. (n. d.). The American Heritage ${ }^{\circledR}$ Stedman's Medical Dictionary. Retrieved September 17, 2014, from http://dictionary.reference.com/browse/concept formation

Creswell, J. W. (2009). Research Design Qualitative, Quantitative, and Mixed Methods Approaches. Sage: USA,

Duit, R. (2007). Students' and teachers' conceptions and science education. Retrieved July 7, 2014, from http://www.ipn.uni-kiel.de/aktuell/stcse/

Finley, F. N., Stewart, J., \& Yarroch, W. L. (1982). Teachers' perceptions of important and difficult science content. Science Education, 66, 531-538. http://dx.doi.org/10.1002/sce.3730660404

Garnett, P. J., \& Treagust, D. F. (1992). Conceptual difficulties experienced by senior high school students of electrochemistry: Electric circuits and oxidation-reduction equations. Journal of Research in Science Teaching, 29(2), 1079-1099. http://dx.doi.org/10.1002/tea.3660291006

Lamanauskas, V., Vilkonien, M., \& Vilkonis, R. (2007). The Chemistry Component of Natural Science Education in Primary and Basic School: Some Major Issues. Bulgarian Journal of Science and Education Policy (BJSEP), 1, 57-75

Losh, S. C., Travani, C. M., Njoroge, R., Wilke, R., \& McAuley, M. (2003). What does education really do? educational dimensions and pseudoscience support in American general public, 1979-2001. Skeptic Inquirer, 27, 30-36.

Nakhleh, M. B. (1992). Why some students don't learn chemistry: Chemical misconceptions. Journal of Chemical Education, 69(3), 191-196. http://dx.doi.org/10.1021/ed069p191

Obomanu, B. J. (2012). Students Conceptual Difficulties in Electrochemistry in Senior Secondary Schools. Journal of Emerging Trends in Educational Research and Policy studies, 3(1), 99-102.

Ogude, A. N., \& Bradley, J. D. (1994). Ionic conduction and electrical neutrality in operating electrochemical cells, Journal of Chemical Education, 71(1), 29-34. http://dx.doi.org/10.1021/ed071p29

Ozkaya, A. R., Uce, M., Saricayir, H., \& Sahin, M. (2006). Effectiveness of a conceptual change-oriented teaching strategy to improve students 'understanding of galvanic cells. Journal of Chemical Education, 83(11), 1719-1723. http://dx.doi.org/10.1021/ed083p1719

Ozmen, H. (2004). Some students' misconceptions in chemistry: A literature review of chemical bonding. Journal of Science Education and Technology, 13(2), 147-159. http://dx.doi.org/10.1023/B:JOST.00000 31255.92943.6d

Sanger, M. J., \& Greenbowe, T. J. (1997). Students' Conceptual Difficulties in electrochemistry: current flow in electrolyte solutions and the salt bridge. Journal of Chemical Education, 74(7), 819-823. http://dx.doi.org/10.1021/ed074p819

Taber, K. S. (1998). The sharing-out of nuclear attraction: Or "I can't think about physics in chemistry". International Journal of Science Education, 20, 1001-1014. http://dx.doi.org/10.1080/0950069980200807.

Vygotsky, L. S. (1978). Mind in society. In M. Cole, V. John-Steiner, S. Scribner, \& S. Souberman (Eds.), The 
development of higher psychological processes. Cambridge, MA: Harvard University Press.

\section{Appendix A}

Table 2. Analysis of secondary school student's conceptual difficulties in electrochemistry

\begin{tabular}{|c|c|c|c|c|c|c|}
\hline $\begin{array}{l}\text { No. of } \\
\text { Items }\end{array}$ & Items Focus & $\begin{array}{c}\text { No. of students } \\
\text { correctly } \\
\text { answered item }\end{array}$ & $\begin{array}{c}\% \text { age of students } \\
\text { correctly } \\
\text { answered item }\end{array}$ & $\begin{array}{c}\text { No. of students } \\
\text { incorrectly } \\
\text { answered item }\end{array}$ & $\begin{array}{c}\% \text { age of students } \\
\text { incorrectly } \\
\text { answered item }\end{array}$ & $\begin{array}{c}\text { Decision } \\
\text { below } 40 \%=\text { difficult, } \\
\text { above } 40 \%=\text { not difficult }\end{array}$ \\
\hline 1 & Redox Reaction & 48 & 33.3 & 96 & 66.7 & Difficult \\
\hline 2 & $\begin{array}{c}\text { Change during } \\
\text { Electrolysis }\end{array}$ & 75 & 52.1 & 69 & 47.9 & Not Difficult \\
\hline 3 & $\begin{array}{c}\text { Product gotten at } \\
\text { Anode }\end{array}$ & 16 & 11.1 & 128 & 88.9 & Difficult \\
\hline 4 & $\begin{array}{l}\text { Charges on } \\
\text { Electrodes }\end{array}$ & 47 & 32.6 & 97 & 67.3 & Difficult \\
\hline 5 & Redox Reaction & 20 & 13.9 & 124 & 86.1 & Difficult \\
\hline 6 & $\begin{array}{c}\text { Calculation of } \\
\text { Oxidation Number }\end{array}$ & 103 & 71.5 & 41 & 28.5 & Not Difficult \\
\hline 7 & $\begin{array}{c}\text { Example of Redox } \\
\text { Reaction }\end{array}$ & 113 & 78.5 & 31 & 21.5 & Not Difficult \\
\hline 8 & Non Electrolyte & 124 & 86.1 & 20 & 13.9 & Not Difficult \\
\hline 9 & Oxidizing Agent & 30 & 20.8 & 114 & 79.2 & Difficult \\
\hline 10 & $\begin{array}{c}\text { Calculation of } \\
\text { Oxidation Number }\end{array}$ & 125 & 86.8 & 19 & 13.2 & Not Difficult \\
\hline 11 & $\begin{array}{c}\text { Definition of } \\
\text { Electrochemical } \\
\text { Cells }\end{array}$ & 75 & 52.1 & 69 & 47.9 & Not Difficult \\
\hline 12 & Electric Circuit & 113 & 78.5 & 31 & 21.5 & Not Difficult \\
\hline 13 & Electric Conductor & 121 & 84.0 & 23 & 16.0 & Not Difficult \\
\hline 14 & Electrodes Charges & 45 & 31.3 & 99 & 68.8 & Difficult \\
\hline 15 & Oxidizing Agent & 44 & 30.5 & 100 & 69.4 & Difficult \\
\hline 16 & $\begin{array}{c}\text { Conduction of } \\
\text { Electrolysis }\end{array}$ & 04 & 2.8 & 140 & 97.2 & Difficult \\
\hline 17 & Oxidation & 50 & 34.7 & 94 & 65.3 & Difficult \\
\hline 18 & $\begin{array}{c}\text { Conduction of } \\
\text { Electrolysis }\end{array}$ & 51 & 35.4 & 93 & 64.6 & Difficult \\
\hline 19 & $\begin{array}{c}\text { Definition of } \\
\text { Electrochemical } \\
\text { Cells } \\
\end{array}$ & 104 & 72.2 & 40 & 27.8 & Not Difficult \\
\hline 20 & $\begin{array}{c}\text { Concept of Anode, } \\
\text { Cathode }\end{array}$ & 44 & 30.5 & 100 & 69.4 & Difficult \\
\hline 21 & $\begin{array}{c}\text { Conduction of } \\
\text { Electrolysis }\end{array}$ & 39 & 27.1 & 105 & 72.9 & Difficult \\
\hline 22 & Reducing Agent & 30 & 20.8 & 114 & 79.2 & Difficult \\
\hline 23 & Concept of Anode & 33 & 22.9 & 111 & 77.1 & Difficult \\
\hline 24 & $\begin{array}{c}\text { Definition of } \\
\text { Oxidation }\end{array}$ & 127 & 88.2 & 17 & 11.8 & Not Difficult \\
\hline 25 & Oxidation State & 47 & 32.6 & 97 & 67.4 & Difficult \\
\hline 26 & Non Conductors & 38 & 26.4 & 106 & 73.6 & Difficult \\
\hline 27 & $\begin{array}{c}\text { Practical } \\
\text { Application of } \\
\text { Electrolysis } \\
\end{array}$ & 11 & 7.6 & 133 & 92.4 & Difficult \\
\hline 28 & $\begin{array}{l}\text { Concept of } \\
\text { Oxidation }\end{array}$ & 28 & 19.4 & 116 & 80.6 & Difficult \\
\hline 29 & Oxidation & 46 & 31.9 & 98 & 68.1 & Difficult \\
\hline 30 & $\begin{array}{c}\text { Oxidizing\& } \\
\text { Reducing Agent }\end{array}$ & 53 & 36.8 & 91 & 63.2 & Difficult \\
\hline
\end{tabular}

\section{Copyrights}

Copyright for this article is retained by the author(s), with first publication rights granted to the journal.

This is an open-access article distributed under the terms and conditions of the Creative Commons Attribution license (http://creativecommons.org/licenses/by/3.0/). 